\title{
Pelaksanaan Pengembangan Keprofesian Berkelanjutan Bagi Guru Sekolah Dasar
}

\author{
Implementation of Continuous Professional Development for Elementary School Teachers
}

\author{
Syamsurijal Basri ${ }^{1 *}$, Andi Nurochmah ${ }^{1}$, Syamsu $K^{1}$ \\ "Email: rijal@unm.ac.id \\ ${ }^{1}$ Program Studi Administrasi Pendidikan, Fakultas Ilmu Pendidikan, Universitas Negeri Makassar
}

Diterima: 15 September 2021 / Disetujui: 24 Desember 2021

\begin{abstract}
ABSTRAK
Tujuan penelitian untuk mengetahui: (1) Gambaran Pelaksanaan Pengembangan Keprofesian Berkelanjutan (PKB) bagi guru Sekolah Dasar (2) Faktor pendukung dan penghambat dalam Pelaksanaan Pengembangan Keprofesian Berkelanjutan bagi guru Sekolah Dasar. Jenis penelitian ini adalah jenis penelitian kualitatif. Hasil penelitian menunjukkan bahwa (1) Pelaksanaan Pengembangan Keprofesian Berkelanjutan bagi guru Sekolah Dasar melalui proses perencanaan program sepenuhnya dilaksanakan melalui forum Kelompok Kerja Guru. Pelaksanaan program dilakukan dengan keikutsertaan para guru dalam berbagai pelatihan, diimplementasikan ke dalam karya inovatif seperti media pembelajaran dan pembuatan video pembelajaran. Evaluasi program dilakukan dengan pembuatan evaluasi diri guru dan laporan yang terkait dengan program. (2) Faktor pendukung pelaksanaan Pengembangan Keprofesian Berkelanjutan adalah kemudahan sumber informasi yang diperoleh dari berbagai pihak yang terpusat pada forum Kelompok Kerja Guru dan sikap antusiasme guru yang tinggi mengikuti program, dukungan kepala sekolah. Sedangkan faktor penghambat adalah belum adanya anggaran khusus yang disiapkan dalam pelaksanaan Pengembangan Keprofesian Berkelanjutan, waktu guru yang terkadang bertabrakan dengan kegiatan lain, dan keterbatasan jaringan internet yang dimiliki untuk melaksanakan Pengembangan Keprofesian Berkelanjutan.
\end{abstract}

Kata Kunci: Pengembangan, Keprofesian Berkelanjutan

\begin{abstract}
The purposes of the study are to discover: (1) an overview of the Implementation of Continuous Professional Development (PKB) for primary School Teachers (2) Supporting and inhibiting factors in the Implementation of Continuous Professional Development (PKB) for primary School Teachers. This type of research is qualitative research using descriptive methods. The results of the study reveal that (1) an Overview of the Implementation of Continuous Professional Development (PKB) for primary school teachers of planning the program PKB fully implemented through the forum of the KKG. The implementation of the program PKB carried out with the participation of teachers in various training then implemented into the innovative work as a medium of learning and the making of the video learning. Program evaluation of PKB is also done with the manufacture of selfevaluation and teacher reports. (2) the supporting Factors in the implementation of PKB among them is the ease of the source of the information obtained from the various parties centralized on the forum of KKG and the attitude of the enthusiasm teachers is high when received information associated with the PKB, especially the support provided by head master of the school. While the inhibiting factors are not yet available funds, time teacher sometimes located in other activities, and the limitations of the internet network for PKB activities.
\end{abstract}

Keywords: Continuous Professional Development.

(c) (9) This work is licensed under Creative Commons Attribution License 4.0 CC-BY International license 


\section{A. PENDAHULUAN}

Pengembangan

Keprofesian

Berkelanjutan (PKB) adalah unsur utama yang kegiatannya juga diberikan angka kredit untuk pengembangan karier guru yang profesional yang mencakup tiga hal, yaitu pengembangan diri, publikasi ilmiah, dan karya inovatif. Selain Pengembangan Keprofesian Berkelanjutan (PKB) masih banyak pendekatan untuk meningkatkan karier dan kualitas pendidik misalnya Penelitian Tindakan Kelas (PTK), lesson study. (Permennegpan dan Birokrasi Nomor 16 Tahun 2009)

Realita yang terjadi bahwa guruguru sekolah dasar utamanya di daerah terpencil kurang memperhatikan pengelolaan kegiatan-kegiatan yang bersifat pengembangan terutama keprofesian, belum melaksanakan publikasi ilmiah dan membuat karya yang inovatif dalam pembelajaran. Guru juga belum memahami cara membuat karya ilmiah dengan benar hal ini disebabkan kegiatan pengembangam profesi yang pernah diikuti hanya bersifat pasif dan hanya mendengarkan materi yang disampaikan oleh pemateri dalam kegiatan pengembanga keprofesian berkelanjutan. Selain itu Guru hanya hadir sebagai perserta dan mendengarkan yang disampaikan para ahli. Melalui kegiatan tersebut diharapkan guru mendapatkan materi baru. Namun, materi yang disampaikan dalam pelatihan pengembangan profesi masih bersifat umum. Sehingga banyak guru mengalami kesulitan dalam menerapkan hasilnya di kelasnya.

Terkait dengan kondisi tersebut maka tujuan dalam penelitian ini untuk mengetahui: 1) Gambaran pelaksanaan Keprofesian Berkelanjutan bagi guru Sekolah Dasar, (2) Faktor Pendukung dan penghambat Pengembangan Keprofesian Berkelanjutan bagi guru Sekolah Dasar. Hal ini merupakan hal baru di tahun 2021 karena peneliti ingin mengetahui pelaksanaan Pengembangan Keprofesian Berkelanjutan pada jenjang sekolah dasar di wilayah kecamatan yang letaknya terpencil.

\section{B. METODE PENELITIAN}

Penelitian ini merupakan penelitian kualitatif, dengan pendekatan deskriptif untuk mengetahui pelaksananan Pengembangan Keprofesian Berkelanjutan (PKB) guru di Sekolah Dasar. Penelitian ini dilakukan di Sekolah Dasar wilayah Kecamatan Tanralili Kabupaten Maros. Subjek penelitian dilakukan secara proposive yaitu koordinator wilayah Pendidikan, 
pengawas sekolah, kepala sekolah, Ketua KKG dan guru. Selanjutnya teknik pengumpulan data yang di gunakan dalam penelitian ini adalah:

1. Wawancara dilakukan secara tidak terstruktur dengan menggunakan pedoman wawancara

2. Observasi dalam penelitian ini pengamatan digunakan untuk mengamati, mengumpulkan data tentang pelaksanaan PKB di lokasi penelitian.

3. Dokumentasi di gunakan untuk menelaah dokumen-dokumen terkait dengan permasalahan.

4. Focus Group Discussion, teknik ini di gunakan untuk memperoleh data dalam bentuk diskusi dengan guru terkait permasalahan yang diteliti.

Kemudian sebelum data dianalisis terlebih dahulu diolah secara ringkas dan sistematis (menulis hasil pengamatan, wawancara, observasi, dokumentasi, dan Focus Group Discussion selanjutnya mengklasifikasi, mereduksi, dan menyajikan). Kegiatan ini berlangsung terus menerus semenjak peneliti mulai memasuki lapangan sehingga analisis data berlangsung selama pengumpulan data.

Secara sederhana, alur analisis data dalam penelitian ini divisualisasikan seperti berikut ini:

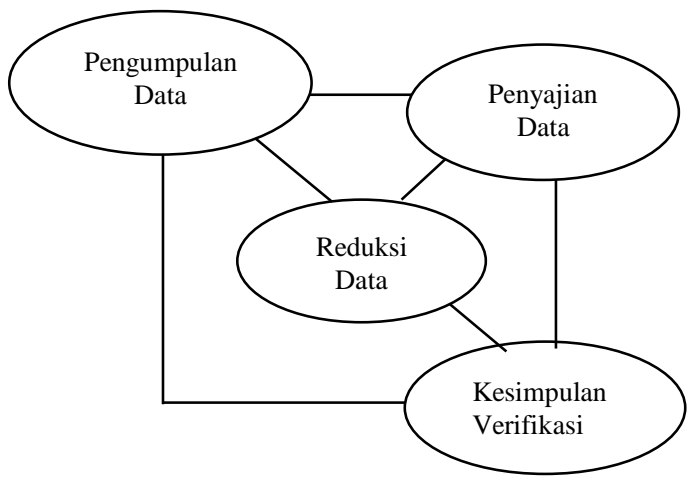

Gambar 1. Komponen dan Alur Analisis Data (Modifikasi dari model Miles dan Huberman dalam Moleong, 2018)

Keempat langkah tersebut dijelaskan sebagai berikut:

1. Mencatat semua temuan fenomena dilapangan melalui observasi, wawancara dokumentasi, dan Focus Group Discussion, dalam bentuk catatan lapangan.

2. Menelaah kembali catatan hasil wawancara, observasi dan studi dokumentasi, Focus Group Discussion serta memisahkan data yang dianggap penting dan tidak penting. Pekerjaan ini diulang kembali untuk memeriksa kemungkinan kekeliruan klarifikasi.

3. Mendeskripsikan data yang telah diklarifikasi untuk kepentingan penelaahan lebih lanjut dengan memperhatikan fokus dan tujuan penelitian.

4. Membuat analisis akhir yang memungkinkan dalam bentuk 
laporan untuk kepentingan penulisan hasil penelitian.

\section{HASIL DAN PEMBAHASAN}

Berdasarkan sumber data dari informasi wawancara, observasi, dan dokumentasi langkah - langkah Pengembangan

Keprofesian

Berkelanjutan telah mengikuti teori yang telah banyak berkembang yaitu diawali dengan proses perencanaan, pelaksanaan, dan evaluasi. Perencanaan Pengembangan Keprofesian Berkelanjutan merupakan kegiatan awal yang dilakukan secara sistematis untuk menyusun rangkaian kegiatan. Perencanaan PKB berlandaskan keadaan dan kebutuhan guru. Proses perencanaan program dilimpahkan pada forum Kelompok Kerja Guru atau lebih dikenal dengan sebutan KKG. Forum KKG menjadi wadah dalam perencanaan program PKB yang dilaksanakan melalui pertemuan rutin guru-guru untuk membahas terkait dengan program yang dibutuhkan oleh guru khususnya PKB. Pembagian waktu pertemuan yang dilaksanakan dua kali dalam satu bulan pada forum $\mathrm{KKG}$ dengan pembagian kelas awal yaitu guru kelas satu, dua, dan tiga pada pertemuan pertama dan kelas tinggi yaitu guru kelas empat, lima, dan enam pada pertemuan kedua akan membahas perencanaan progam PKB yang akan dilaksanakan. Selain pengembangan diri dan publikasi ilmiah, program PKB selanjutnya adalah karya inovatif yang merupakan karya yang bersifat pengembangan, modifikasi atau penemuan baru. Karya inovatif ini sebagai bentuk kontribusi guru terhadap peningkatan kualitas proses pembelajaran di sekolah dan pengembangan dunia pendidikan, sains, teknologi, dan seni.

Pelaksanaan program PKB khususnya pengembangan diri dilaksanakan melalui diklat fungsional yang diadakan oleh berbagai pihak penyelenggara pelatihan seperti Dinas Pendidikan, Balai Pengembangan Penjaminan Mutu Pendidikan Vokasi bidang Kelautan Perikanan Teknologi Informasi dan Komunikasi atau BPPMPV KPTK, dan Lembaga Penjaminan Mutu Pendidikan atau LPMP. Selain itu, program pengembangan diri pada PKB juga terkadang diadakan oleh forum KKG. Pelaksanaan program PKB selanjutnya adalah publikasi ilmiah, terlihat bahwa guru sekolah dasar masih kurang dalam hal membuat PTK sehingga publikasi ilmiah belum dilakukan selama dua tahun terakhir. Selain pengembangan diri dan publikasi ilmiah, pelaksanaan program PKB selanjutnya adalah karya inovatif. Pelaksanaan program PKB 
berupa karya inovatif guru sekolah dasar telah berjalan dengan baik. Hal ini ditunjukkan dengan berbagai karya inovatif yang dibuat oleh guru untuk memudahkan peserta didik menerima materi pembelajaran yang diberikan khususnya pengembangan video pembelajaran.

Evaluasi dilakukan untuk mengetahui ketercapaian program PKB baik berupa pengembangan diri, publikasi ilmiah, dan karya inovatif. Evaluasi program PKB guru sekolah dasar telah berjalan dengan baik. Hal ini ditunjukkan dengan pelaksanaan evaluasi yang terpusat di forum $\mathrm{KKG}$ untuk melihat ketercapaian program PKB yang telah dilaksanakan oleh guru. Evaluasi program PKB juga dilakukan dengan pembuatan evaluasi diri guru dan laporan yang terkait dengan program PKB yang telah diikuti. Laporan tersebut juga disampaikan kepada kepala sekolah sebagai laporan untuk selanjutnya disampaikan kepada Dinas Pendidikan.

Pelaksanaan program PKB memiliki faktor pendukung yang mendukung kesuksesan dalam pelaksanaan PKB khususnya pada guru sekolah dasar. Faktor pendukung tersebut adalah adanya forum KKG yang memberikan wadah sebagai sumber informasi terbaru dalam pelaksanaan program PKB khususnya pengembangan diri. Kemudahan sumber informasi yang diperoleh dari berbagai pihak yang terlibat seperti koordinator wilayah, Dinas Pendidikan, maupun LPMP dalam pelaksanaan PKB melalui forum KKG. Sehingga informasi yang terkait dengan pelaksanaan PKB dapat disampaikan kepada guru secara keseluruhan. Tidak hanya itu, antusiasme guru yang tinggi saat menerima informasi terkait dengan PKB, terlebih lagi dukungan yang diberikan oleh kepala sekolah, membuat kegiatan yang dilakukan dapat diterima dengan baik. Semangat guru dalam mempelajari hal yang baru dan terus ingin belajar merupakan upaya untuk dapat menjadi guru yang lebih profesional.

Faktor penghambat yang ditemukan adalah belum tersedianya anggaran khusus yang disiapkan dalam pelaksanaan PKB. Sehingga pelaksanaan PKB seperti pengembangan diri, publikasi ilmiah, dan karya inovatif masih menggunakan dana mandiri dari guru yang melaksanakan PKB. Selain itu beberapa faktor penghambat lainnya seperti waktu pelaksanaan PKB yang terkadang bersamaan dengan kegiatan guru sehingga guru tidak sempat lagi mengikuti pelaksanaan PKB. Keterbatasan jaringan 
internet juga menjadi faktor penghambat bagi guru yang ingin mengikuti PKB terlebih lagi beberapa kegiatan pengembangan diri berupa pelatihanpelatihan dilakukan secara daring.

Profesionalisme pendidik sangat berhubungan erat dengan mutu pendidikan, sebab proses belajar mengajar sebagai inti dari pendidikan akan sangat tergantung pada kualitas tenaga pendidik yang profesional dan kualitas hasil beajar merupakan ujung tombak kualitas pendidikan. Program PKB hadir agar guru dapat memelihara, meningkatkan dan memperluas pengetahuan dan keterampilannya serta membangun kualitas pribadi yang dibutuhkan di dalam kehidupan profesionalnya (Mulyono, 2020). Proses perencanaan dalam pelaksanaan PKB bagi guru Sekolah Dasar dilakukan berlandaskan keadaan dan kebutuhan guru. Proses perencanaan program PKB dilimpahkan pada forum Kelompok Kerja Guru atau lebih dikenal dengan sebutan KKG. Perencanaan program PKB baik berupa pengembangan diri, publikasi ilmiah, dan karya inovatif disusun melalui pertemuan yang diadakan di forum KKG bersama koordinator wilayah, ketua KKG, dan para guru. Pertemuan rutin yang dilakukan sebanyak dua kali dalam satu bulan dijadikan sebagai wadah untuk mendapatkan informasi terkait dengan PKB.

Menurut Suyanto dan Jihad (2018) menjelaksan bahwa KKG merupakan salah satu wadah profesional guru (baik guru kelas maupun guru mata pelajaran) yang berada pada suatu wilayah kabupaten/kota/kecamatan/sanggar/ gugus sekolah adalah organisasi sekolah nonstruktural yang bersifat mandiri, berasaskan kekeluargaan, dan tidak mempunyai hubungan hirarkis dengan lembaga lain. KKG mewadahi kegiatan profesional guru terutama yang bertanggungjawab untuk mengelola kegiatan belajar mengajar di kelas sebagai guru kelas.

Pelaksanaan PKB khususnya pengembangan diri dilaksanakan melalui diklat fungsional atau seminar yang diadakan oleh berbagai pihak penyelenggara pelatihan seperti Balai Pengembangan Penjaminan Mutu Pendidikan Vokasi bidang Kelautan Perikanan Teknologi Informasi dan Komunikasi atau BPPMPV KPTK, Dinas Pendidikan setempat, LPMP, dan termasuk KKG. Para narasumber akan dihadirkan sesuai dengan materi pelatihan yang akan disampaikan. Sejalan dengan hal tersebut Kastawati dan Nurkolis (2019) melalui jurnalnya menjelaskan 
bahwa PKB berupa pengembangan diri yang paling banyak digunakan saat ini dilakukan dengan metode pelatihan, kuliah, simulasi, diskusi, dan pemodelan perilaku. Pengembangan diri dilakukan melalui lembaga kerja sama antara pemerintah daerah dengan lembaga penyelenggara diklat dengan model on job training.

Nainggolan (2018) dalam jurnal administrasi sekolah menjelaskan bahwa pelatihan dengan model on the job training ini sebagai upaya memfasilitasi peningkatan pengetahuan guru terkait pekerjaan, keterampilan, dan perilaku. (Aini, 2018) juga menunjukkan bahwa pelatihan dengan model on the job training mempunyai pengaruh yang signifikan terhadap peningkatan kemampuan dan kompetensi guru.

Pelaksanaan program PKB selanjutnya dapat dilakukan oleh guru dengan melaksanakan penelitian khususnya Penelitian Tindakan Kelas atau lebih dikenal dengan PTK. Hasil penelitian PTK diseminarkan dan dipublikasikan melalui jurnal ilmiah. Menurut Sunuharyo (2018) bahwa penelitian tindakan kelas adalah penelitian yang dilakukan di dalam kelas menggunakan suatu tindakan untuk meningkatkan kualitas proses belajar mengajar agar diperoleh hasil yang lebih baik dari sebelumnya. Penelitian tindakan kelas membutuhkan waktu yang tidak sebentar karena guru sebagai peneliti harus bisa mengimplementasikan tindakan beserta variabel yang sudah dirancang untuk mencapai hasil yang dikehendaki. Penelitian tindakan kelas atau PTK tidak bisa diselesaikan hanya dalam waktu yang singkat. Namun hasil yang Bapak/Ibu dapatkan melalui PTK ini bisa dipublikasikan menjadi jurnal publikasi ilmiah dalam konteks Pengembangan Keprofesian Berkelanjutan atau PKB (Aini, 2018). Selain pengembangan diri dan publikasi ilmiah, pelaksanaan program PKB selanjutnya adalah karya inovatif. Karya inovatif merupakan karya yang bersifat pengembangan, modifikasi atau penemuan baru. Sebagai bentuk kontribusi guru terhadap peningkatan kualitas proses pembelajaran di sekolah dan pengembangan dunia pendidikan, sains/teknologi, dan seni. Pelaksanaan program PKB berupa karya inovatif yang dilakukan oleh guru Sekolah Dasar telah berjalan dengan baik. Hal ini ditunjukkan dengan kemampuan para guru dalam menerima materi pelatihan kemudian diimplementasikan ke dalam karya inovatif berupa pembuatan video 
pembelajaran dan media pembelajaran yang sesuai dengan materi atau bahan ajar yang akan disampaikan kepada peserta didik. Hal ini bertujuan agar menarik minat belajar dan memudahkan peserta didik dalam menerima pembelajaran. Sejalan dengan penjelasan Waryono (2018) bahwa karya inovatif merupakan bagian dari kegiatan PKB yang memiliki kedudukan yang sama dengan publikasi ilmiah yang merupakan bagian dari PKB tersebut. Keduanya atau salah satu harus dikembangkan guru yang bergolongan III/b ke atas agar lebih profesional dalam pekerjaannya. Hasil secara fisik dari PKB tersebut dapat diajukan sebagai perolehan angka kredit untuk kenaikan Pangkat/jabatan guru yang bersangkutan.

Evaluasi dilakukan untuk mengetahui ketercapaian pada pelaksanaan PKB yang telah dilakukan. Sebagaimana penjelasan Tatang M (2010) bahwa evaluasi adalah suatu tindakan atau proses yang dilakukan untuk menentukan nilai dari pelaksanaan program kerja yang telah dilakukan. Evaluasi program PKB yang dilakukan oleh guru sekolah dasar dipusatkan pada forum KKG. Kegiatan pertemuan rutin yang diadakan oleh forum KKG sekaligus melakukan evaluasi secara berkesinambungan kepada para guru yang telah melaksanakan program
PKB yang ditunjukkan dengan evaluasi diri guru. Laporan tersebut kemudian diserahkan kepada forum KKG sebagai bahan perencanaan program PKB di masa mendatang. Laporan tersebut juga disampaikan kepada kepala sekolah sebagai laporan untuk selanjutnya disampaikan kepada Dinas Pendidikan.

Suyanto dan Jihad (2018) menjelaskan bahwa dalam mengevaluasi program PKB terdapat dua kegiatan utama. Kedua kegiatan utama itu adalah evaluasi diri guru (EDG) yang dilakukan secara mandiri dan penilaian kinerja guru (PKG) yang dilakukan oleh penilai eksternal yang ditunjuk dan ditetapkan untuk itu. Dari hasil penilaian internal dan eksternal itu akan diperoleh gambaran tentang kompetensi guru. Dari gambaran itu akan terlihat hal yang harus diperbaiki dan hal yang harus ditingkatkan dan dikembangankan khususnya pada pelaksanaan PKB.

Pelaksanaan PKB tidak terlepas dari beberapa faktor pendukung yang membuat terlaksananya program PKB dengan baik. Faktor pendukung tersebut adalah adanya forum KKG yang memberikan wadah sebagai sumber informasi terbaru dalam pelaksanaan program PKB khususnya pengembangan diri melalui kegiatan pelatihan. 
Kemudahan sumber informasi yang diperoleh dari berbagai pihak yang terlibat seperti koordinator wilayah, pihak dinas pendidikan, maupun LPMP dalam pelaksanaan PKB yang terpusat pada forum KKG. Sehingga informasi yang terkait dengan pelaksanaan PKB dapat disampaikan kepada guru secara keseluruhan. Sejalan dengan penjelasan Mulyono (2020) bahwa kegiatan KKG yang dilakukan di sekolah telah banyak membantu upaya peningkatan kualitas dan mutu pembelajaran. Hal ini tentunya harus dapat ditingkatkan terus menerus dengan meningkatkan kerja sama kemitraan antara guru yang tergabung dalam gugus KKG. Pelaksanaan PKB juga didukung dengan sikap antusiasme guru yang tinggi saat menerima informasi terkait dengan PKB ditambah lagi dengan dukungan yang diberikan oleh kepala sekolah, membuat kegiatan yang dilakukan dapat diterima dengan baik. Semangat guru dalam mempelajari hal yang baru dan terus ingin belajar merupakan upaya untuk dapat menjadi guru yang lebih profesional.

Pelaksanaan PKB juga tidak terlepas dari beberapa faktor penghambat dalam pelaksanaan program PKB. Faktor penghambat tersebut adalah keterbatasan anggaran yang dapat digunakan. Sehingga harus dilakukan melalui pendanaan secara mandiri. Selain terkendala dana, pelaksanaan PKB juga terkendala oleh waktu yang kurang tepat saat pelaksanaan PKB berlansung. Tidak hanya itu, keterbatasan jaringan internet juga menjadi faktor penghambat bagi guru yang ingin mengikuti $\mathrm{PKB}$ terlebih lagi beberapa kegiatan pengembangan diri berupa pelatihan-pelatihan dilakukan secara daring. Sejalan dengan hal tersebut, melalui jurnalnya Maksum (2015) menjelaskan bahwa dalam pelaksanaan PKB juga terkadang terhambat dari ketersediaan atau kurangnya sarana dan prasarana pendukung khususnya ketersediaan jaringan internet. Kendala umum pelaksanaan $\mathrm{PKB}$ juga bersumber dari guru itu sendiri walaupun kepala sekolah sudah memberikan dukungan.

\section{KESIMPULAN DAN SARAN}

Hasil penelitian dan pembahasan dapat ditarik kesimpulan bahwa pelakasanaan Pengembangan Keprofesian Berkelanjutan (PKB) bagi guru Sekolah Dasar secara keseluruhan telah berjalan cukup baik. Perencanaan program PKB sepenuhnya dilaksanakan melalui forum KKG sebagai wadah untuk mendapatkan informasi terkait dengan PKB baik berupa pengembangan diri, publikasi ilmiah, dan 
karya inovatif. Pelaksanaan program PKB dilakukan dengan keikutsertaan para guru dalam berbagai pelatihan yang diadakan sebagai bentuk pengembangan diri. Hasil dari pelatihan diimplementasikan ke dalam beberapa karya inovatif seperti media pembelajaran dan pembuatan video pembelajaran yang memudahkan peserta didik memahami materi atau bahan ajar yang disampaikan oleh guru. Publikasi ilmiah melalui pembuatan PTK belum berjalan dengan optimal yang terlihat dari kurangnya guru yang melakukan penelitian khususnya penelitian tindakan kelas. Evaluasi program PKB dilakukan dengan pembuatan evaluasi diri guru dan laporan yang terkait dengan program PKB yang telah diikuti oleh guru yang bersangkautan sebagai bahan perencanaan program PKB di masa mendatang.

Faktor pendukung dalam pelaksanaan PKB diantaranya adalah kemudahan sumber informasi yang diperoleh dari berbagai pihak yang terpusat pada forum $\mathrm{KKG}$ dan sikap antusiasme guru yang tinggi saat menerima informasi terkait dengan PKB, adanya dukungan kepala sekolah, membuat kegiatan yang dilakukan dapat dilakukan dengan baik. Sedangkan faktor penghambat dalam pelaksanaan PKB adalah belum adanya anggaran khusus yang disiapkan dalam pelaksanaan PKB, waktu guru yang terkadang bertabrakan dengan kegiatan lain, dan keterbatasan jaringan internet yang dimiliki untuk melaksanakan PKB

\section{DAFTAR PUSTAKA}

Aini. (2018). Model Pengembangan PKB Guru Di SMK Provinsi DKI Jakarta. Jurnal Kebijakan dan Pengembangan Pendidikan, 2(1).

Dirjen PMPTK. (2010). Pedoman Pengelolaan Pengembangan Keprofesionalan Berkelanjutan (PKB). Departemen Pendidikan Nasional Republik Indonesia.

Indonesia, P. R. (2003). Undang-undang Republik Indonesia nomor 20 tahun 2003 tentang sistem pendidikan nasional.

Kastawati, \& Nurkolis, S. (2019). Pengembangan Keprofesian Berkelanjutan Guru untuk Meningkatkan Mutu Pendidikan. Kelola Jurnal Manajemen Pendidikan, 6(2).

Maksum. (2015). Pelaksanaan Pengembangan Keprofesian Berkelanjutan Guru Kelas SD Negeri 2 Tarakan. Jurnal Kebijakan dan Pengembangan Pendidikan, $3(1)$.

Moleong, J. . (2018). Metodologi Penelitian Kualitatif. PT Remaja Rosdakarya.

Mulyono. (2020). Manajemen Pengembangan Keprofesian Berkelanjutan (PKB) Bagi Guru dan Kepala Sekolah. Jurnal Manajemen Pendidikan Islam, 5(2).

Nainggolan, W. .(2018). Pengaruh On The Job Training Dan Off The Job Training Terhadap Kinerja Guru. Jurnal Administrasi Sekolah, 6(3).

Sunuharyo. (2018). Asesmen Kebutuhan Pengembangan Profesionalisme 
Guru SMK. Jurnal Pendidikan

Humaniora, 1(1).

Suyanto, \& Jihad, A. (2018). Menjadi

Guru Profesional (Strategi

Meningkatkan Kualifikasi dan

Kualitas Guru di Era Global. Esensi

Erlangga Group.

Tatang M, A. (2010). Manajemen

Pendidikan. UNY Press.

Waryono. (2018). Menjadi Guru

Profesional melalui Penyusunan

Karya Inovatif. Jurnal Administrasi

Pendidikan, 1(3). 